\title{
The influence of yellow lupin intercropped with spring triticale on predatory carabid beetles (Coleoptera: Carabidae)
}

\author{
Micha£ HUREJ and JACEK P. TWARDOWSKI
}

Department of Plant Protection, Agricultural University, Cybulskiego 32, 50-205 Wrocław, Poland; e-mail: hurej@ozi.ar.wroc.pl

Key words. Carabid beetles, Pseudoophonus rufipes, abundance, activity, intercropping, yellow lupin, spring triticale, shelter

\begin{abstract}
Intercropping may have a positive effect on the abundance and activity of carabid beetles and therefore their response to intercropping yellow lupin with spring triticale was studied for a period of three years (2001-2003). Carabids were most numerous in yellow lupin monoculture and in the intercrop with the highest proportion of lupin. Important differences between the experimental treatments were found, but they were mostly non-significant because of the great variation between samples. It is supposed that the positive effect of lupin on carabid beetles was due to the shelter it provides. During the three-year study 59 species of carabid beetles were recorded. The most abundant species in each treatment was Pseudoophonus rufipes. Irrespective of the experimental treatment, this species was caught in the greatest numbers towards the end of each growing season. This was probably because of the greater soil coverage provided by the larger lupin plants at the end of the season.
\end{abstract}

\section{INTRODUCTION}

In intercropping more than one crop is grown in an area simultaneously, in such a way that they interact agronomically (Vandermeer, 1989). This type of cropping can suppress weed growth, and insect damage is often lower in such polycultures than in monocultures (Root, 1973; Altieri \& Letourneau, 1982; Theunissen, 1994).

Carabid beetles (Coleoptera: Carabidae), appear to be successful as generalist predators in controlling many crop pests, including aphids (Dunning et al., 1975; Sunderland, 2002). The effect of plant diversity on populations of Carabidae is well studied (Alderweireldt \& Desender, 1990; Tonhasca, 1993; Carcamo \& Spence, 1994). Increased biodiversity may provide benefits for the carabids by offering them a more stable and favourable microhabitat (Hance, 1978). Booij et al. (1997) record that intercropping of e.g. cabbage with clover had a positive effect on the abundance of carabid beetles.

The main object of this study was to compare the species composition and abundance of carabid beetles in yellow lupin intercropped with spring triticale. In Poland mixtures of these plants are grown for feeding to ruminants.

\section{MATERIAL AND METHODS}

The occurrence of carabid beetles in mixed crops of yellow lupin (cv. Markiz) and spring triticale (cv. Wanad) was studied at the Experimental Research Station at Pawłowice near Wrocław, Lower Silesia, Poland, for three seasons (2001-2003). The mixtures and the monoculture were grown in plots of 15 square meter size $(10 \mathrm{~m} \times 1.5 \mathrm{~m})$ on sandy soil. The $0.3 \mathrm{~m}$ wide space between the experimental plots was maintained mechanically as a bare soil and the plots were weeded. The experiment was designed as a split-plot with four replicates for each mixture of plants. Lupin and triticale were sown at 6 different rates (Table 1).

The abundance of adult carabid beetles was recorded using pitfall traps. Each trap was a glass jar, $90 \mathrm{~mm}$ diameter and 110 $\mathrm{mm}$ high. In the bottom of each trap was placed $100 \%$ ethylene glycol, which acted as a killing and preserving agent. Traps were protected from rainfall by plastic covers mounted $10 \mathrm{~cm}$ above the trap opening. There were four traps in each monoculture and mixture of plants (one trap in the middle of each plot). Traps were emptied once a week, from the time when the plants germinated to the end of the growing season. Insects were counted and identified to species in the laboratory.

Seasonal abundance of the Pseudoophonus rufipes, the most numerous species, was graphically plotted as the average number of beetles captured per trap in each sampling period. The results were analysed using analysis of variance (ANOVA) and the Tukey HSD (honest significant difference) test. In all statistical analysis, a significance level of 5\% was used. The response variable was the number of $P$. rufipes and the factor the treatment.

\section{RESULTS AND DISCUSSION}

\section{Species richness and abundance}

In Table 2, only the most numerous species of carabids are presented. A total of 1442 specimens in 2001, 1752 in 2002 and 1253 in 2003 were captured by the pitfall traps. During the three years of the study carabid beetles were most abundant in the yellow lupin monoculture. The beetles were also abundant in the mixture with the lowest proportion of spring triticale. In term of total catch the tendency was for beetle numbers to decrease with increasing proportion of triticale in the mixture. In two out of

TABLE 1. Number of yellow lupin and spring triticale seeds sown per $1 \mathrm{~m}^{2}$ in the different treatments.

\begin{tabular}{cccc}
\hline Treatment & Yellow lupin & Spring triticale & $\begin{array}{c}\% \text { of yellow lupin } \\
\text { seed in mixture }\end{array}$ \\
\hline 1 & 100 & - & 100 \\
2 & 80 & 80 & 50 \\
3 & 60 & 160 & 27 \\
4 & 40 & 240 & 14 \\
5 & 20 & 320 & 6 \\
6 & - & 400 & - \\
\hline
\end{tabular}

In 2001 carabids were trapped in treatments 1, 3, 4 and 6, and in 2002 and 2003 in treatments 1, 2, 3, 5 and 6. 


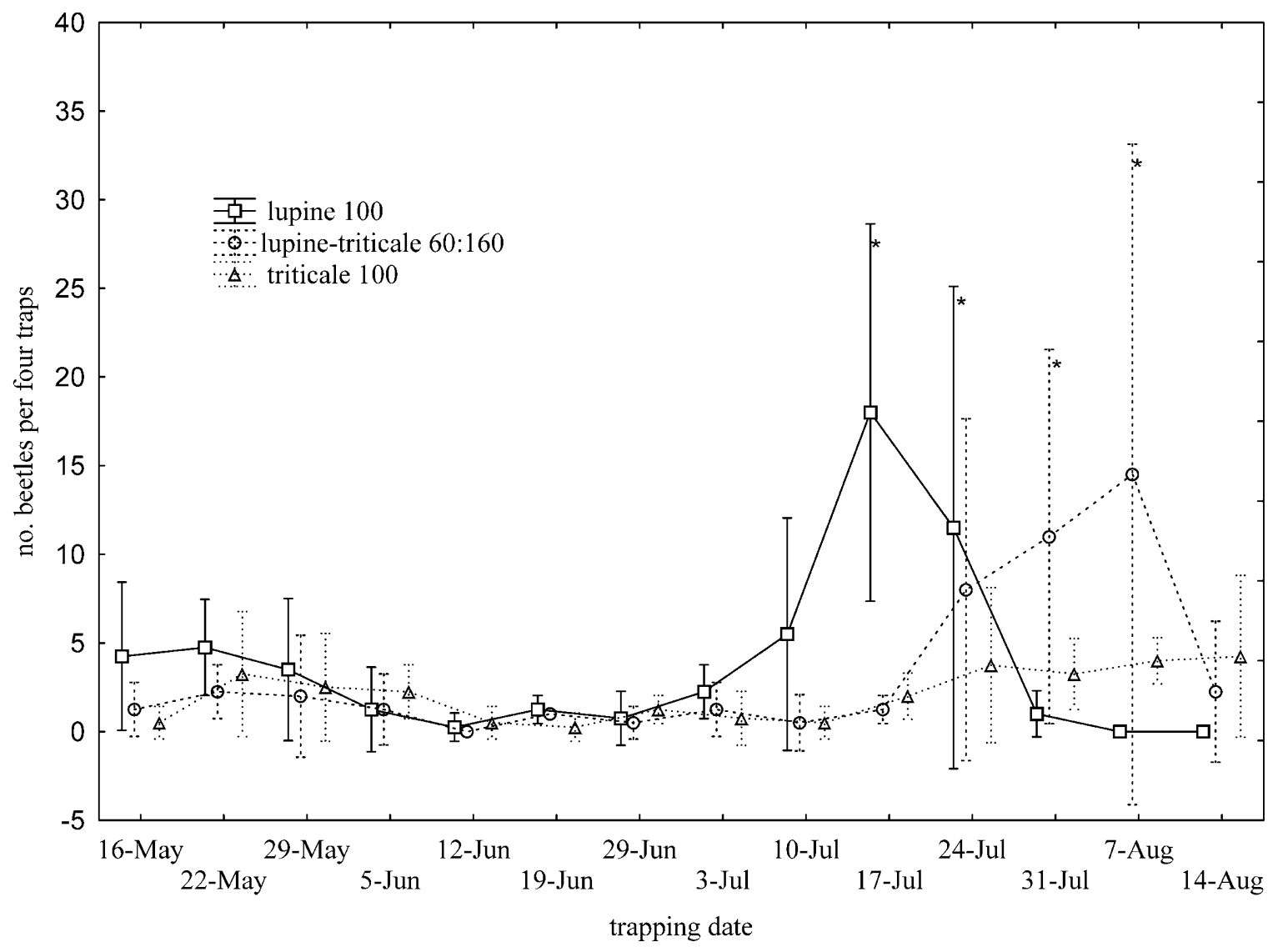

Fig. 1. Seasonal changes in abundance of Pseudoophonus rufipes in treatments 1, 3 and 6 in 2001. (ANOVA; Tukey HSD test, $p=$ $0.05)$, *significant difference. The lines indicate mean number of beetles caught. Whiskers indicate Standard Deviation (SD).

TABLE 2. The most numerous species of carabid beetles collected in 2001, 2002 and 2003.

\begin{tabular}{|c|c|c|c|c|c|c|c|c|c|c|c|c|c|c|c|c|c|}
\hline \multirow{2}{*}{ Species } & \multicolumn{4}{|c|}{2001} & \multirow{2}{*}{ Total - } & \multicolumn{5}{|c|}{2002} & \multirow{2}{*}{ - Total } & \multicolumn{5}{|c|}{2003} & \multirow{2}{*}{ Total } \\
\hline & $1 *$ & 3 & 4 & 6 & & 1 & 2 & 3 & 5 & 6 & & 1 & 2 & 3 & 5 & 6 & \\
\hline Pseudoophonus rufipes (De Geer) & 217 & 187 & 154 & 110 & 668 & 330 & 290 & 258 & 217 & 217 & 1312 & 193 & 124 & 120 & 112 & 68 & 617 \\
\hline Broscus cephalotes (L.) & 67 & 39 & 31 & 31 & 168 & 38 & 23 & 12 & 6 & 12 & 91 & 35 & 47 & 24 & 24 & 22 & 152 \\
\hline Bembidion quadrimaculatum (L.) & 12 & 2 & & 5 & 19 & 1 & 8 & 3 & 3 & 21 & 36 & 7 & 23 & 17 & 18 & 42 & 107 \\
\hline Bembidion lampros (Herbst) & 6 & 12 & 10 & 10 & 38 & 2 & 4 & 5 & 2 & 6 & 19 & 5 & & 4 & 3 & 2 & 14 \\
\hline Bembidion femoratum (Sturm) & 25 & 8 & 2 & 7 & 42 & 5 & 2 & 2 & 7 & 8 & 24 & & & & & & \\
\hline Harpalus affinis (Schrank) & 5 & 6 & 7 & 12 & 30 & 1 & 5 & 3 & 6 & 4 & 19 & 19 & 16 & 15 & 12 & 21 & 83 \\
\hline Harpalus tardus (Panz.) & & & & & & & & & & & & 4 & 12 & 4 & 7 & 2 & 29 \\
\hline Calathus fuscipes (Goeze) & 39 & 46 & 56 & 48 & 189 & 8 & 10 & 5 & 5 & & 28 & & & & & & \\
\hline Calathus melanocephalus (L.) & 16 & 31 & 22 & 15 & 84 & 5 & 3 & 2 & 2 & 2 & 14 & & & & & & \\
\hline Calathus erratus (Sahl.) & 6 & 13 & 6 & 12 & 37 & & & & & & & & & & & & \\
\hline Amara plebeja (Gyll.) & 15 & 18 & 13 & 5 & 51 & & & & & & & & & & & & \\
\hline Amara aulica (Panz.) & & & & & & 7 & 9 & 11 & 7 & 17 & 51 & & & & & & \\
\hline Clivina fossor (L.) & & & & & & 9 & 17 & 14 & 7 & 7 & 54 & 9 & 8 & 8 & 8 & 4 & 37 \\
\hline Anisodactylus binotatus (Fabr.) & & & & & & & & & & & & 14 & 7 & 6 & 6 & 15 & 48 \\
\hline $\begin{array}{c}\text { Other species, } \\
\text { total no. of specimens }\end{array}$ & 20 & 42 & 33 & 26 & 121 & 26 & 26 & 26 & 19 & 7 & 104 & 35 & 37 & 29 & 32 & 29 & 162 \\
\hline Total number & 427 & 403 & 331 & 281 & 1442 & 432 & 397 & 341 & 281 & 301 & 1752 & 321 & 274 & 227 & 2 & 208 & 1253 \\
\hline Number of species & 20 & 21 & 23 & 24 & 32 & 24 & 27 & 24 & 22 & 15 & 41 & 30 & 29 & 26 & 22 & 26 & 45 \\
\hline
\end{tabular}

* Treatment (see Table 1). 
the three years (2001 and 2003), the lowest number of carabids was found in the triticale monoculture. It is likely that the pure stands of yellow lupin and the intercrop with the least triticale provided the most favourable microclimate (higher air humidity) for this epigeal group of arthropods.

In 2001, 32 species of Carabidae were identified, 41 in 2002 and 45 in 2003. Altogether, 59 species were caught over the three years (Table 2). The most abundant species in each plot was Pseudoophonus rufipes, which made up from $46 \%$ to $75 \%$ of the catch in each year. Other numerous species were: Broscus cephalotes, Calathus fuscipes and Bembidion spp. P. rufipes responded negatively to an increase in the proportion of triticale in a mixture as did the overall number of beetles.

\section{Seasonal dynamics}

Seasonal dynamics presented in Fig. 1 is that of Pseudoophonus rufipes, which was the most abundant species in all three years. To show more clearly the effect of intercropping on the dynamics of $P$. rufipes the results for only two of the treatments were included in this figure. In 2001, in all three treatments presented in the figure, $P$. rufipes was captured in small numbers from mid-May to the beginning of July. The highest number of this species (72) was recorded in the lupin monoculture on July $17^{\text {th }}$. The maximum number of beetles in the lupintriticale mixture 60:160 (58 insects) was recorded later, on August $7^{\text {th }}$. Significant differences between this treatment and the others occurred on July $31^{\text {st }}\left(\mathrm{F}_{3,65}=3.12 ; p<0.001\right)$ and on August $7^{\text {th }}\left(\mathrm{F}_{3,130}=5.29 ; p<0.001\right)$. On both these dates, significantly more beetles were captured in the intercrop. In triticale monoculture this species was trapped in small numbers throughout the growing period. The high numbers of carabid beetles caught later in the season was probably a consequence of the better soil coverage provided for them by the bigger lupin plants.

In 2002 and 2003, the seasonal dynamics of $P$. rufipes are very similar to that recorded in 2001 , and because of this the results are not presented in the figures. In these two years there were no significant differences in beetle numbers caught in the various plots at any time.

\section{CONCLUSIONS}

Carabid beetles were most numerous in yellow lupin monocultures and the intercrop with the highest proportion of lupin. Therefore, it is suggested that yellow lupin can provide a sheltered habitat for carabid beetles.
The most abundant species in all the treatments was Pseudoophonus rufipes. It was captured in small numbers up to the end of June and then increased in abundance at the beginning of July and remained abundant until harvest time.

ACKNOWLEDGEMENTS. This research was supported by grant No. 6 P06R 05221 from State Committee for Scientific Research, Poland.

\section{REFERENCES}

Alderweireldt M. \& Desender K. 1990: Microhabitat preference of spiders (Araneae) and carabid beetles (Coleoptera, Carabidae) in maize fields. Med. Fac. Landbouww. Rijksuniv. Gent 55: 501-510.

Altieri M.A. \& Letourneau D.K. 1982: Vegetation management and biological control in agroecosystems. Crop Prot. 1: 405-430.

Booij C.J.H., Noorlander J. \& Theunissen J. 1997: Intercropping cabbage with clover: effects on ground beetles. Biol. Agric. Hortic. 15: 261-268.

Carcamo H.A. \& Spence J.R. 1994: Crop type effects on the activity and distribution of ground beetles (Coleoptera: Carabidae). Environ. Entomol. 23: 684-692.

DunNing R.A., BaKer A.N. \& Windley R.F. 1975: Carabids in sugar beet crops and their possible role as aphid predators. Ann. Appl. Biol. 80: 125-128.

HANCE T. 2002: Impact of cultivation and crop husbandry practices. In Holland J.M. (eds): The Agroecology of Carabid Beetles. Intercept, Andover, pp. 231-249.

Rоот R.B. 1973: Organization of a plant-arthropod association in simple and diverse habitats: the fauna of collards (Brassica oleracea). Ecol. Monogr. 43: 94-125.

SUNDERLAND K.D. 2002: Invertebrate pest control by carabids. In Holland J.M. (ed.): The Agroecology of Carabid Beetles. Intercept, Andover, pp. 165-214.

THeUNISSEN J. 1994: Intercropping in field vegetable crops: pest management by agrosystem diversification-an overview. Pest. Sci. 42: 65-68.

Tonhasca A. 1993: Carabid beetle assemblage under diversified agroecosystems. Entomol. Exp. Appl. 68: 279-285.

VANDERMEER J.H. 1989: The Ecology of Intercropping. Cambridge Univ. Press., 337 pp.

Received September 23, 2004; revised and accepted August 7, 2005 